\title{
Oxidative stress in five wheat varieties (Triticum aestivum L.) exposed to water stress and study of their antioxidant enzyme defense system, water stress responsive metabolites and $\mathrm{H}_{2} \mathrm{O}_{2}$ accumulation
}

\author{
Usha Chakraborty ${ }^{\text {* }}$, Bhumika Pradhan ${ }^{1}$ \\ ${ }^{1}$ Department of Botany, University of North Bengal, Siliguri, India. \\ *Corresponding author: chakrabortyusha@hotmail.com \\ Received: May 25, 2012; Accepted: July 03, 2012
}

\begin{abstract}
Five varieties of wheat (Triticum aestivum L.) - KW, UP 2752, PBW 343, S0 and LV - were subjected to water stress and sampling was done on the $3^{\text {rd }}, 6^{\text {th }}$ and $9^{\text {th }}$ day of stress. RWC decline in KW, UP 2752 and PBW 343 (36.65, 42.34 and $40.75 \%$ respectively) was comparatively lesser than in LV and SO (52.93 and $52.67 \%$ respectively). In all varieties tested, three antioxidant enzymes (POX, APOX and GR) showed an initial increase. The activity of POX and GR increased with the increase in the duration of stress in KW, UP 2752 and PBW 343, while the activity of APOX declined. However, CAT and SOD showed an initial increase in these varieties, whereas it declined in SO and LV with increase in the period of stress. Accumulation of $\mathrm{H}_{2} \mathrm{O}_{2}$ declined during prolonged water stress in KW, UP 2752 and PBW 343, while it increased in LV and S0. The accumulation of MDA content was three times higher in susceptible varieties than in tolerant varieties. The content of proline, phenol and ascorbate increased during water stress whereas the accumulation of carotenoid showed a significant decrease after showing an initial increase in the tested varieties. Higher values of total antioxidant and MSI were recorded in KW, UP 2752 and PBW 343 during stress while after 6 days MSI declined in LV and SO. During water stress there was a general decline in the total chlorophyll content. Analyzing the data, the present work suggested that out of the five varieties, KW, UP 2752 and PBW 343 showed more tolerance to water stress than SO and LV.
\end{abstract}

Keywords: antioxidants, carotenoids, drought, lipid peroxidation.

Abbreviations: APOX: ascorbate peroxidase (EC.1.11.1.11); CAT: catalase (EC.1.11.1.6); CMS: cell membrane stability; DAB: diaminobenzidine; EC: electrical conductivity; GR: glutathione reductase (EC 1.6.4.2); $\mathrm{H}_{2} \mathrm{O}_{2}$ : hydrogen peroxide; KW: Kaweri; LV: Iocal variety; MDA: malondialdehyde; MSI: membrane stability index; NBT: nitro blue tetrazolium; PPO: polyphenol oxidase; POX: peroxidase (EC. 1.11.17); RH: relative humidity; ROS: reactive oxygen species; RWC: relative water content; SO: Sonalika; SOD: superoxide dismutase (EC 1.15.1.1); TBA: thiobarbituric acid; TCA: trichloroacetic acid. 


\section{INTRODUCTION}

Tas and Tas (2007) have defined drought as one of the environmental stresses, which is the most significant factor restricting plant growth and crop productivity in the majority of agricultural fields of the world. In general, drought is responsible for several metabolic processes of plants, with photosynthetic apparatus being one of the most important (Nayyar and Gupta, 2006). Besides changes in photosynthesis, such adverse effects on metabolism lead to growth inhibition, stomata closure with consecutive reduction of transpiration, which are considered necessary for coping with osmotic changes in their tissues (Lawlor and Cornic, 2002; Yordanov et al., 2003; Zhu, 2002). Water stress leads to the formation of ROS, which are extremely harmful to the plants. Gratão et al. (2005) suggested that to prevent or alleviate injuries from ROS, plants have evolved an antioxidant defense system that includes non-enzymatic compounds, like ascorbate, glutathione, tocopherol, carotenoids, flavonoids and enzymes such as SOD, CAT, POX, APOX, GR and PPO. Similar views were also expressed earlier by authors as Mittler (2002) and Gechev et al. (2002). According to Imlay (2003), water-stress conditions may trigger an increased formation of the superoxide radical and $\mathrm{H}_{2} \mathrm{O}_{2}$ which can inactive $\mathrm{SH}$-containing enzymes and directly attack membrane lipids. Gratão et al. (2005) suggested that in higher plants GR is involved in defense against oxidative stress, being responsible for the reduction of oxidized glutathione for the chain reactions of scavenging $\mathrm{H}_{2} \mathrm{O}_{2}$ by APX and GPX, that might be completed and continued. They further postulated that SOD acts as the first line of defense against ROS and that it is responsible for the dismutation of $\mathrm{O}_{2}^{-}$into $\mathrm{H}_{2} \mathrm{O}_{2}$. The $\mathrm{H}_{2} \mathrm{O}_{2}$ liberated in the peroxisome is metabolized by CAT following the conversion of glycolate to glyoxylate during photorespiration into $\mathrm{H}_{2} \mathrm{O}$ and $\mathrm{O}_{2}$, while NADPH-dependent reduction of oxidized GSSG to the reduce form GSH is catalyzed by GR (Gratão et al., 2005). The utilization of multiple isoforms of enzymes is one of the primary control mechanisms of cellular metabolism in plants (Sang et al., 2005).

Generation of ROS also leads to lipid peroxidation (Chen et al., 2000). Foyer and Noctor (2000) suggested that the central factor in both biotic and abiotic stress, which occurs during imbalance in any cell compartment between the production of ROS and antioxidant defense system is oxidative stress which leads to a varied degree of physiological challenges. They further suggest that since ROS have multiple functions therefore in spite of being a harmful molecule, the cells have developed mechanisms to control the concentrations of ROS and they are not completely eliminated (Foyer and Noctor, 2000). Foyer and Noctor (2003) suggested that ROS can be viewed as cellular indicators of stress and secondary messengers involved in all aspects of plant biology from gene expression and translation to enzyme chemistry.

$\mathrm{H}_{2} \mathrm{O}_{2}$ is a non-radical ROS produced in a twoelectron reduction of molecular oxygen. Several sites have been recognized as $\mathrm{H}_{2} \mathrm{O}_{2}$ sources, including organelles (mitochondria, peroxisomes and chloroplasts), the apoplastic and the plasma membrane as well as cell-wall associated enzymes (various NADPH oxidases and PERs). According to Upadhyaya et al. (2007) environmental stresses are known to induce $\mathrm{H}_{2} \mathrm{O}_{2}$ and other toxic oxygen species production in cellular compartments, resulting in acceleration of leaf senescence through lipid peroxidation and other oxidative damage. As $\mathrm{H}_{2} \mathrm{O}_{2}$ is a strong oxidant, it can initiate localized oxidative damage in leaf cells leading to disruption of metabolic function and loss of cellular integrity, actions that result in senescence promotion. The role of $\mathrm{H}_{2} \mathrm{O}_{2}$ in stressinduced damage has long been recognized, but it is now also generally accepted that $\mathrm{H}_{2} \mathrm{O}_{2}$ is an integral component of cell signaling cascades (Mittler, 2002; Vranova et al., 2002) and an indispensable second messenger in biotic and abiotic stress situations (Pastori and Foyer, 2002).

The overproduction of $\mathrm{H}_{2} \mathrm{O}_{2}$ has been observed in plants exposed to a number of stress conditions and is considered as one of the factors causing oxidative stress (Snyrychova, 2009). According to Foyer and Noctor (2012), out of the various forms of ROS, the central role in plant signaling, regulating plant development and adaptation to abiotic and biotic stresses, is played by $\mathrm{H}_{2} \mathrm{O}_{2}$. Increased availability of $\mathrm{H}_{2} \mathrm{O}_{2}$ is a commonly observed feature of plant stress response signature. The physiological context involves a continuous supply of environmental stimuli that can trigger intracellular $\mathrm{H}_{2} \mathrm{O}_{2}$ accumulation or modulate the response to such accumulation.

With physiological parameters as CMS, differences in the tolerance for compound stresses, such as salinity and water deficiency, can be detected. Measurement of CMS is one technique that has often been used for screening against drought tolerance in various crops, as rice (Tripathy et al., 2000), wheat and wild relatives of wheat (Farooq and Azam, 2002), for example. Suzuki et al. (2012) has studied the networks of ROS/redox signaling in the chloroplast and mitochondria and suggested that they play essential roles in the acclimation of plants to abiotic stresses, these signals contributing to a delicate balance of homeostasis within each organelle, as well as to cross-talk between different cellular components by regulating important biological pathways such as gene expression, energy metabolism and protein phosphorylation under stress condition. 
The present work was undertaken to evaluate the oxidative stress and the antioxidant response system in 1-month-old wheat plant subjected sequentially to water stress with a detailed study on the accumulation of $\mathrm{H}_{2} \mathrm{O}_{2}$ and its in situ detection in the leaf of the stressed and control plants.

\section{MATERIAL AND METHODS}

Plant material and experimental conditions: Seeds of commercially relevant lines of five wheat (Triticum aestivum L.) varieties (KW, LV, UP 2752, PBW 343 and SO) were selected for experimental purposes. LV and $\mathrm{KW}$ are popularly grown in the fields of this region. UP 2752, PBW 343 and SO were obtained from the research station of Uttar Banga Krishi Vishwavidyalaya (UBKV). They were selected as all are locally grown and a comparison of their responses could give a better understanding of the susceptibility/tolerance to the different varieties to drought. The seeds were surface sterilized for 3 to 5 min with $0.1 \%(w / v) \mathrm{HgCl}_{2}$ solution, washed twice with sterile double-distilled water. The seeds were then transferred to petriplates maintaining aseptic conditions to avoid contamination. One-week-old seedlings were selected and transferred to earthen pots with soil containing a suitable amount of manure and the pots were labeled. The transferred seedlings in the pots were then maintained in growth chamber at a favorable temperature of 20 to $25^{\circ} \mathrm{C}, 65$ to $70 \%$ of $\mathrm{RH}$, standard photoperiod of 16 hours, and $400 \mu \mathrm{mol} \mathrm{m} \mathrm{m}^{-2} \mathrm{~s}^{-1}$ irradiance. To impart water stress, watering of the plant was completely withheld for the test period, when the plants were 1-month-old. Drought stress was induced in 1-month-old plants by withholding water completely for specific period. Sampling of the plant was done on the $3^{\text {rd }}, 6^{\text {th }}$ and $9^{\text {th }}$ day to study the response of plants to varied days of drought. After the $9^{\text {th }}$ day, i.e. from $10^{\text {th }}$ day, the leaves showed severe wilting symptoms in all varieties so the sampling was done to till $9^{\text {th }}$ day. In all estimations, sampling was also done at zero day of drought, which was considered as control. RWC, which is considered one of the important test to assess the water content during stress, was calculated by the formula as given by Farooqui et al. (2000):

$$
\text { RWC }(\%)=\frac{\text { fresh weight }- \text { dry weight }}{\text { fully turgid weight }- \text { dry weight }} \times 100
$$

The biochemical assays of the plant were done as given below.

\section{Extraction and assays of antioxidant enzyme}

Preparation of extracts: The extraction of enzymes from the plant was done by homogenizing the leaves of 1-month-old plant using liquid nitrogen inanice-cold50-mM sodium phosphate buffer of $\mathrm{pH} 7.2$ along with $1 \%(\mathrm{w} / \mathrm{v})$ polyvinylpolypyrrolidone by a pre-chilled mortar and pestle. Centrifugation of the homogenized mixture was done at $6,708 \mathrm{~g}^{\mathrm{n}}$ for $20 \mathrm{~min}$ at $4^{\circ} \mathrm{C}$. The supernatant was directly used for various enzymatic assays as crude enzyme extract. The quantification of soluble protein present in the extract was done by Lowry's method (Lowry et al., 1951) utilizing bovine serum albumin (BSA) as standard.

\section{Assay of antioxidant enzymes}

POX (EC. 1.11.17): its activity was assayed spectrophotometrically as described by Chakraborty et al. (1993) with some modifications using 4802 UV VIS spectrophotometer (Cole Parmer, USA). Specific activity was expressed as mmol o-dianisidine oxidized $\mathrm{mg}$ protein $^{-1} \mathrm{~min}^{-1}$.

APOX (EC.1.11.1.11): its assay was done by using the method described by Asada and Takahashi (1987) with some minor modification. Enzyme activity was expressed as $\mathrm{mmol}$ ascorbate oxidized $\mathrm{mg}$ protein-1 $\mathrm{min}^{-1}$.

CAT (EC.1.11.1.6): its activity was measured by estimating the breakdown of $\mathrm{H}_{2} \mathrm{O}_{2}$, which was determined at $240 \mathrm{~nm}$ as described by Beers and Sizer (1952). The enzyme activity was expressed as $\mu \mathrm{mol}_{2} \mathrm{O}_{2}$ mg protein ${ }^{-1} \mathrm{~min}^{-1}$.

GR (C 1.6.4.2): the activity of GR was determined by using the method described by Lee and Lee (2000) by measuring the oxidation of NADPH at $340 \mathrm{~nm}$. Enzyme activity was expressed as $\mu \mathrm{M}$ NADPH oxidized mg protein ${ }^{-1}$ min $^{-1}$.

SOD (EC 1.15.1.1): after some minor modification, the method as proposed by Dhindsa et al. (1981) was used for the assay of the activity of SOD, in which the inhibition of the photochemical reduction of NBT was monitored. One unit of activity was defined as the amount of enzyme required to inhibit $50 \%$ of the NBT reduction rate in the controls containing no enzymes.

$\mathrm{H}_{2} \mathrm{O}_{2}$ quantification and its in situ detection: The $\mathrm{H}_{2} \mathrm{O}_{2}$ in the leaf samples were quantified and the estimation was done following the method described by Jena and Choudhuri (1981). A specific amount of the leaf samples were weighed and homogenized in $50 \mathrm{mM}$ potassium phosphate buffer (pH 6.5), which was then centrifuged at $2,415 \mathrm{~g}^{\mathrm{n}}$ for 25 
min, and the supernatant was used for $\mathrm{H}_{2} \mathrm{O}_{2}$ determination. All the extractions and estimations were done in minimal light conditions (Chakraborty and Pradhan, 2011).

The reaction was completed as an intense yellow color started developing. This was was monitored at $410 \mathrm{~nm}$ spectrophotometrically. The levels of $\mathrm{H}_{2} \mathrm{O}_{2}$ in the samples were determined by the use of extinction

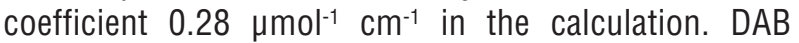
staining technique described by Thordal-Christensen et al. (1997) was used with some minor modifications (Chakraborty and Pradhan, 2011) to detect the in situ levels of $\mathrm{H}_{2} \mathrm{O}_{2}$ in the leaf samples. Vacuum infiltration of the leaf discs (20 $\mathrm{mm}$ in diameter) was done with $D A B$ $(\mathrm{pH} 3.8)$ at a rate of $1 \mathrm{mg} / \mathrm{mL}$. Incubation of the leaf was done in dark for 24 hours at $30^{\circ} \mathrm{C}$ with a continuous stirring of the leaf at $150 \mathrm{rpm}$ followed by their transfer to $90 \%$ ethanol at $70^{\circ} \mathrm{C}$ in water bath for the removal of chlorophyll. The polymerization of DAB at the site of activity of the enzyme POX was achieved locally and instantly in the treated leaf samples. The development of reddish-brown color was the result of polymerization of $D A B$ with $\mathrm{H}_{2} \mathrm{O}_{2}$ at the site of their production.

Determination of lipid peroxidation: The accumulation of MDA content, a measure of lipid peroxidation was monitored by the TBA reaction. A sample of $0.25 \mathrm{~g}$ of the leaf was homogenized in $0.1 \%(\mathrm{w} / \mathrm{v})$ TCA. Centrifuge was done for 10 min at $6,708 \mathrm{~g}^{\mathrm{n}}$ and $2 \mathrm{~mL}$ of $20 \%$ TCA containing $0.5 \%(\mathrm{w} / \mathrm{v})$ TBA were added to $0.5 \mathrm{~mL}$ of the supernatant obtained followed by heating of the mixture for $30 \mathrm{~min}$ at $95^{\circ} \mathrm{C}$ followed by cooling it on ice. The absorbance of the sample was determined at 600 and $532 \mathrm{~nm}$. Using an extinction coefficient of $155 \mathrm{mM}^{-1} \mathrm{~cm}^{-1}$ (Heath and Packer, 1968) the concentration of MDA was calculated.

Extraction and estimation of non-enzymatic antioxidants: Carotenoids were extracted in methanol and, for the estimation, the method described by Lichtenthaler (1987) was used. Extraction was done in methanol and the extract was filtered. Absorbance of the filtrate was noted at 480, 663 and $645 \mathrm{~nm}$ in a VIS spectrophotometer (Systronics, India, Model 101) and the content of carotenoid was determined by the formula as given below:

$A_{480}-\left(1.144 \times A_{663}-0.638 A_{645}\right)$

For the extraction and estimation of ascorbic acid (ascorbate) the method as given by Mukherjee and Chaudhuri (1983) was used.

Total antioxidant activity or free radical scavenging activity was measured by following the method of
(Blois, 1958) and expressed as percent (\%) inhibition of DPPH absorbance, which was measured at $515 \mathrm{~nm}$. The percentage inhibition of the absorbance of the solution of DPPH was determined by the formula as described by Chakraborty and Pradhan (2011). Total antioxidant activity was thus measured as free radical scavenging ability in terms of inhibition of absorbance by DPPH.

MSI (Membrane stability index): Leaf MSI was determined according to the method of Premchandra et al. (1990), as modified by Sairam (1994). Leaf discs $(100 \mathrm{mg}$ ) were thoroughly washed in running tap water followed by washing with double distilled water thereafter the discs were heated in $10 \mathrm{~mL}$ of double distilled water at $40^{\circ} \mathrm{C}$ for $30 \mathrm{~min}$. Then EC (C1) was recorded by EC meter. Subsequently the same samples were place in a boiling water bath $\left(100^{\circ} \mathrm{C}\right)$ for 10 min and their EC was also recorded (C2) in a conductivity meter (Labindia) with $\mathrm{K}=0.946$, cell constant $=1$, solution condition $=84 \mu \mathrm{S}$, coefficient -1 at $25^{\circ} \mathrm{C}$. The MSI was calculated as:

$\mathrm{MSI}=[1-(\mathrm{C} 1 / \mathrm{C} 2)] \times 100$

Extraction and estimation of biochemical components: The sample leaf was extracted by the method as given by Mahadevan and Sridhar (1982) and, for the quantification, the method of Bray and Thorpe (1954) was used. $3 \%$ sulphosalicylic acid was used for the extraction of free proline in the leaf sample from the plants and the estimation was done by using the method of Bates et al. (1973). The extraction of chlorophyll was done in $80 \%$ acetone and, for the estimation of total chlorophyll, chlorophyll a (chl a) and chlorophyll b (chl b), the method given by Harborne (1973) was used.

\section{RESULTS}

Morphological responses and relative water content of leaves: The plants of all the five varieties under test showed less or no symptoms of wilting till the 6 to $7^{\text {th }}$ day of stress, however severe wilting occurred in the plants after $9^{\text {th }}$ days of stress more pronounced in varieties LV and SO. RWC in the leaf of all the varieties declined remarkably as the severity of stress in terms of days was increased (Figure 1). Our data showed that the decrease in RWC was significantly lower in case of PBW 343, UP 2752 and KW on the $9^{\text {th }}$ day of stress when compared to their respective controls $(40.75,42.34$ and $36.65 \%$, respectively) however the decline in RWC was much more in LV and SO with respect to their controls (52.93 and $52.67 \%$, respectively). 
Antioxidative enzyme activities in wheat after water stress: In the present study, activities of APOX (Figure 2) and GR (Figure 3) showed a significant increase in all the tested wheat varieties during the initial 3 days of stress. As the severity or the duration of stress was increased, the activity of APOX declined in all the five varieties; however activity of GR continued to increase with the increase in the days of stress in KW, UP 2752 and PBW 343 but declined in case of SO and LV. In case of CAT (Figure 4) and SOD (Figure 5), activities showed an increase in the initial stages of stresses, i.e. during the $3^{\text {rd }}$ day of water stress in three varieties. However, in case of LV and SO, the

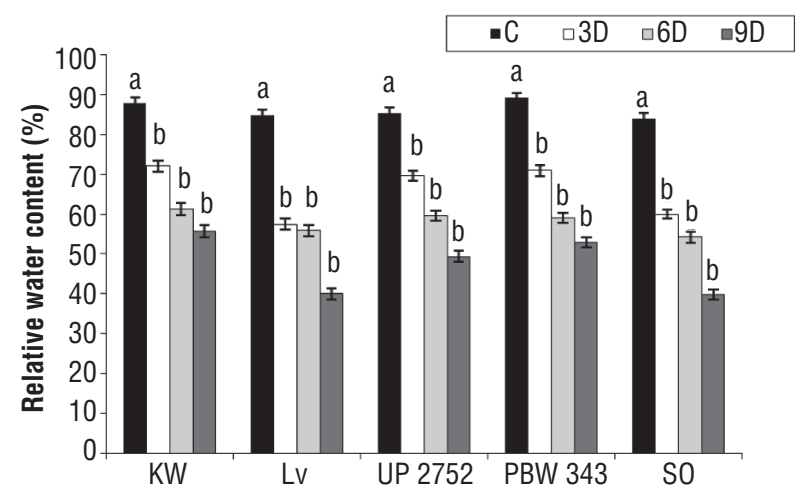

Figure 1. Relative water content of five varieties of wheat subjected to water stress treatments. Results are expressed as the mean of three replicates (ten plants each). Bars represent standard error. Different letters indicate significant differences with respect to control $(p<0.01)$. C: control; 3,6 and $9 \mathrm{D}$ : days after withholding water.

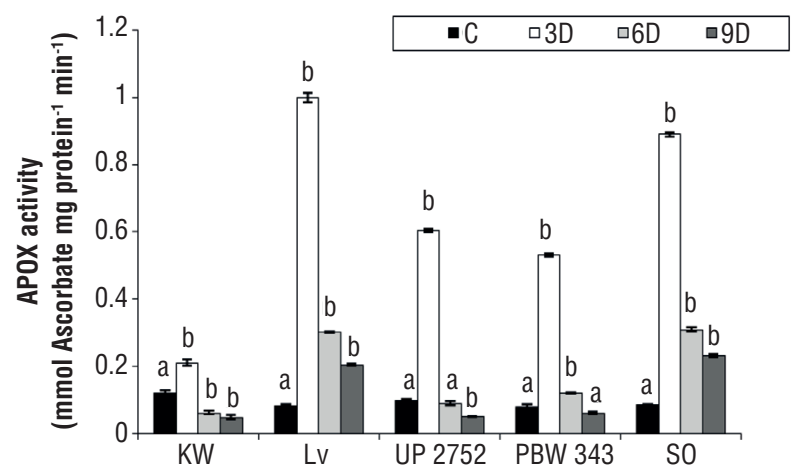

Figure 2. Ascorbate peroxidase activities in five varieties of wheat subjected to water stress treatments. Results are expressed as mean of three replicates (ten plants each). Bars represent standard error. Different letters indicate significant differences with respect to control $(p<0.01)$. C: control; 3, 6 and 9 D: days after withholding water. activity of CAT and SOD showed a general decline with increase in the severity of water stress, while in the other three varieties the activity of these two enzymes declined during the later period of water stress. It was noted that the activity of POX enhanced greatly with increase in the period of stress in KW, UP 2752 and PBW 343 whereas in LV and S0, the activity declined (Figure 6).

$\mathrm{H}_{2} \mathrm{O}_{2}$ accumulation and its in situ levels, and change in MDA content in the leaf of wheat during water stress: The accumulation of $\mathrm{H}_{2} \mathrm{O}_{2}$ and lipid peroxidation increased with increase in the days of stress. The accumulation was higher in case of LV, SO following

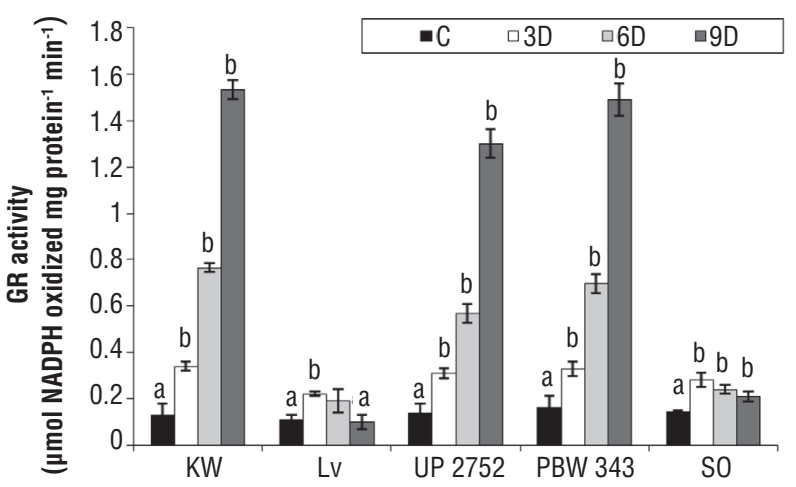

Figure 3. Glutathione reductase (GR) activities in five varieties of wheat subjected to water stress treatments. Results are expressed as mean of three replicates (ten plants each). Bars represent standard error. Different letters indicate significant differences with respect to control $(p<0.01)$. C: control; 3,6 and $9 \mathrm{D}$ : days after withholding water.

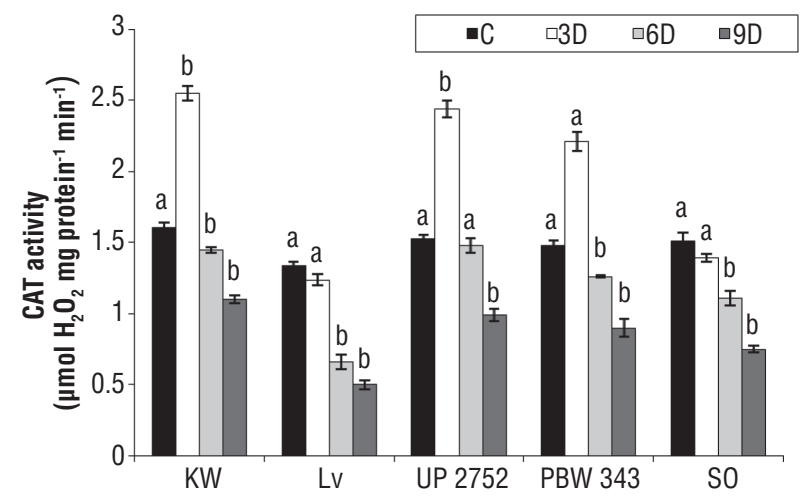

Figure 4. Catalase activities in five varieties of wheat subjected to water stress treatments. Results are expressed as mean of three replicates (ten plants each). Bars represent standard error. Different letters indicate significant differences with respect to control $(p<0.01)$. C: control; 3, 6 and 9 D: days after withholding water. 
water stress and lower in case of KW, UP 2752 and PBW 343 (Figure 7A). Lipid peroxidation is measured in terms of MDA content which during water stress was found to be thrice in SO and LV than in KW, UP 2752 and PBW 343 (Figure 7B). It also showed a general increase with the increase in the severity of water stress with respect to their respective controls.

During microscopic studies of the leaf tissues in DAB staining test, dark-brown spots were observed as big and small patches at the site of DAB polymerization. The leaf of SO and LV showed more darkly stained

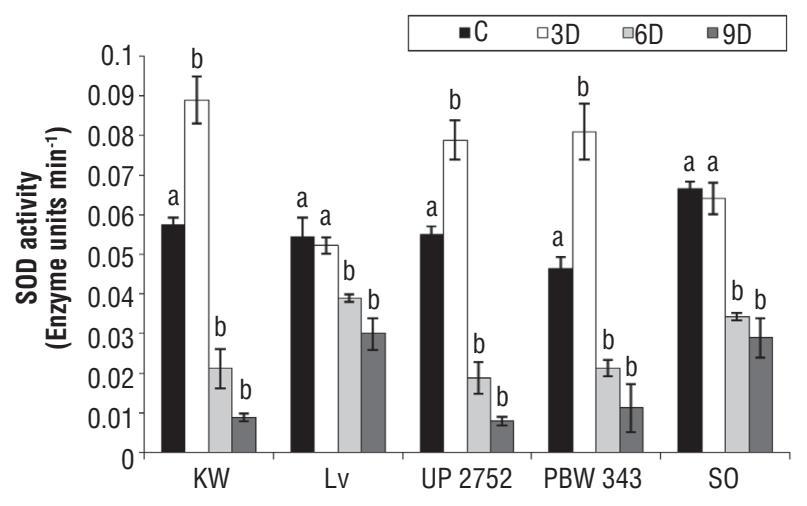

Figure 5. Superoxide dismutase activities in five varieties of wheat subjected to water stress treatments. Results are expressed as mean of three replicates (ten plants each). Bars represent standard error. Different letters indicate significant differences with respect to control $(p<0.01)$. C: control; 3, 6 and 9 D: days after withholding water.

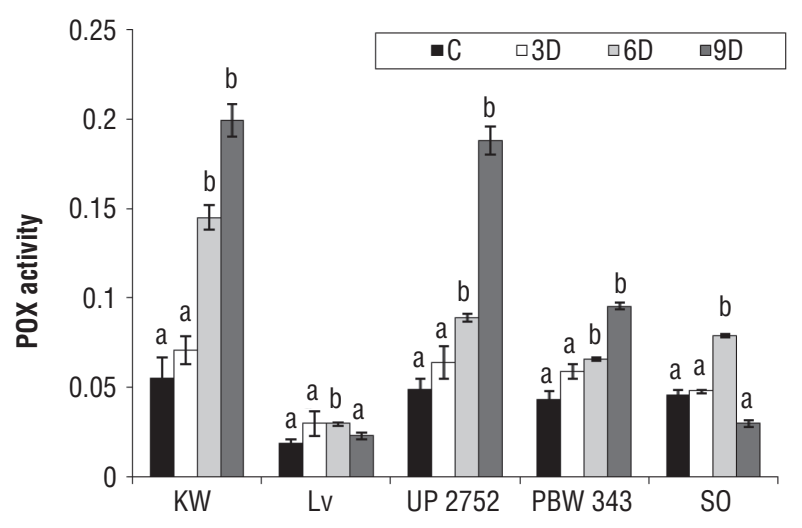

Figure 6. Peroxidase activities in five varieties of wheat subjected to water stress treatments. Results are expressed as mean of three replicates (ten plants each). Bars represent standard error. Different letters indicate significant differences with respect to control $(p<0.01)$. C: control; 3, 6 and 9 D: days after withholding water.
$D A B$-sites in the tissues than in the leaves from the other three varieties with respect to their control. With increase in the duration of stress LV and SO showed darker staining in the leaf tissues particularly during the $6^{\text {th }}$ and $9^{\text {th }}$ day of stress; however, the other varieties also showed darker stained leaf tissues during the $9^{\text {th }}$ day of water stress (Figure 8). Interestingly, DAB polymerization site was largely localized at the tip of the leaf, region surrounding the middle lamella and also the stomata of the leaf in the varieties under stress when compared to the leaf of the control set of GY (Figure 9). The transverse section of the leaf at the stained site showed that the $D A B$ binding sites were localized mostly in the peripheral region of the cell (Figure 9).

Changes in ascorbate, carotenoids, total antioxidants and chlorophyll content of the leaf: Following water stress there was a significant increase in the two antioxidants,

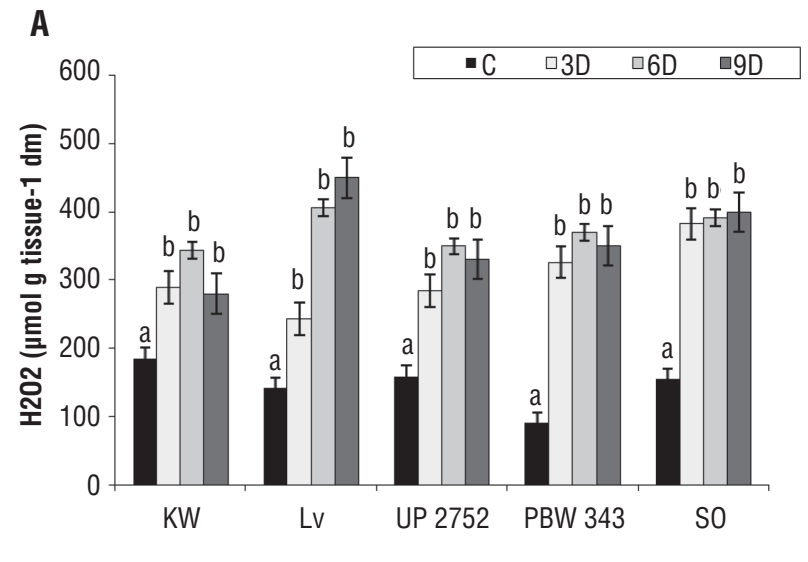

B

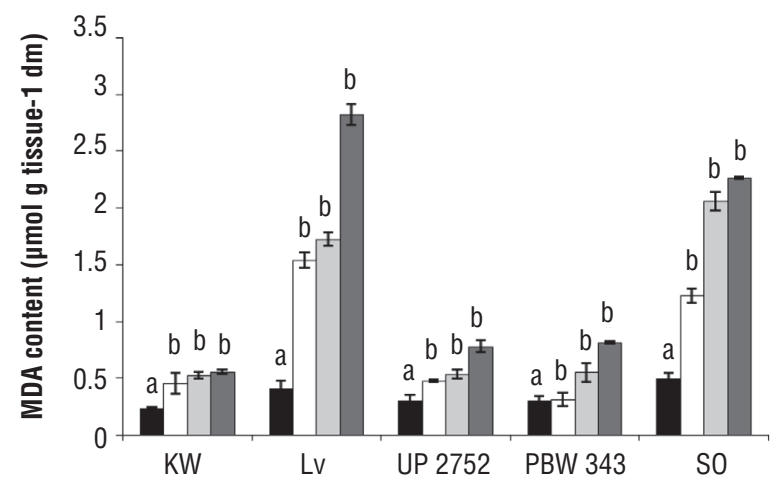

Figure 7. Effect of water stress on accumulation of $\mathrm{H}_{2} \mathrm{O}_{2}(\mathrm{~A})$ and lipid peroxidation (B) (expressed as MDA content) in five varieties of wheat. Results are expressed as mean of three replicates (ten plants each). Bars represent standard error. Different letters indicate significant differences with respect to control $(p<0.01)$. C: control; 3,6 and $9 \mathrm{D}$ : days after withholding water. 

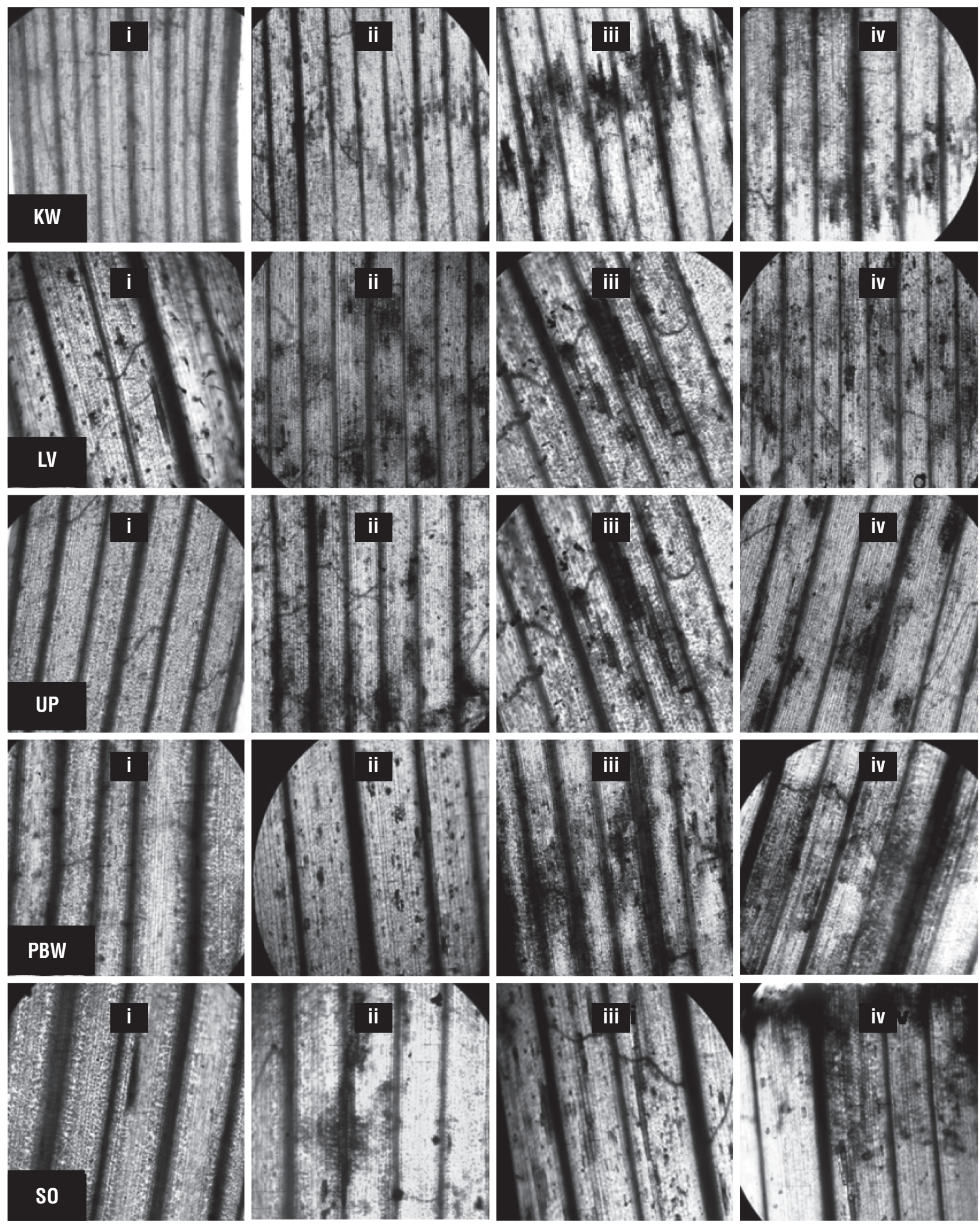

Figure 8. In situ detection of $\mathrm{H}_{2} \mathrm{O}_{2}$ in mid-portions of leaves of five varieties (KW, LV, UP 2,752, PBW 343 and SO) of wheat following water stress. i: control; ii: 3 days of water stress; iii: 6 days of water stress; iv: 9 days of water stress. 

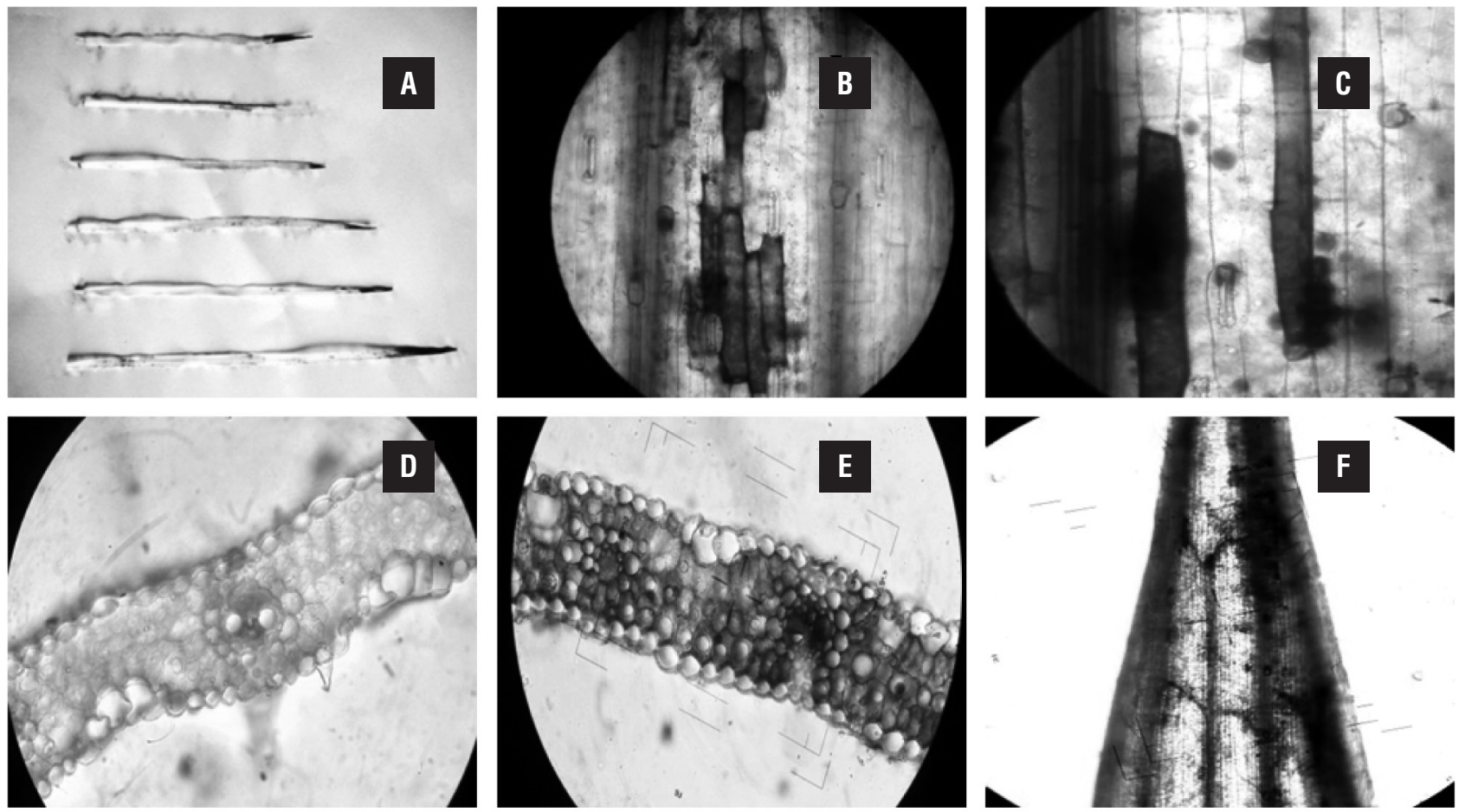

F
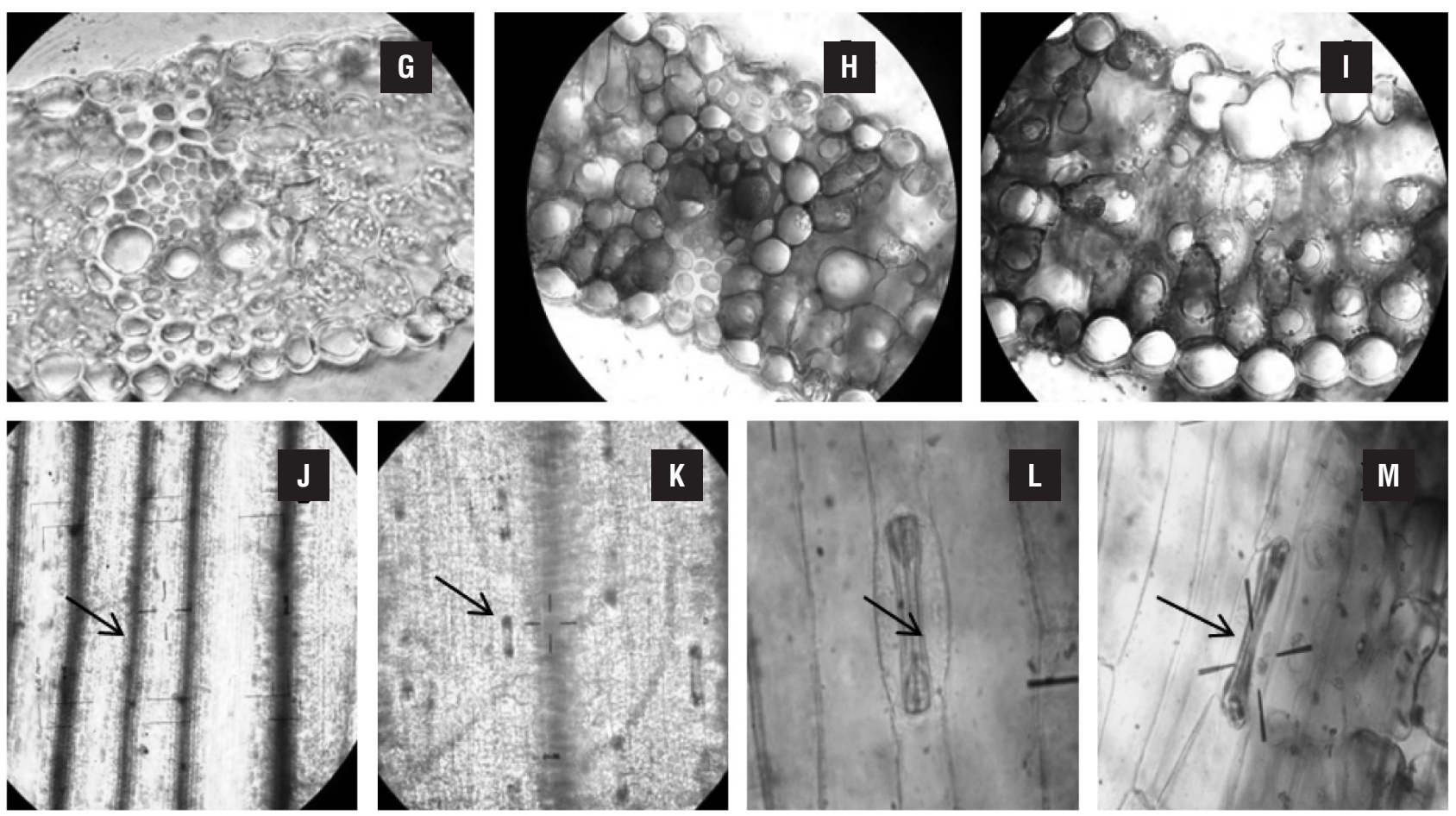

Figure 9. Diaminobenzidine stained sites shown as dark brown spots in the GY variety of leaf. (A) full length leaves; (B-C) $10 x$ view of group of cells in the stressed leaf of $6^{\text {th }}$ day; $(D-E)$ t.s. of control leaf and drought stressed leaf respectively; $(F)$ tip portion of leaf; $(\mathrm{G}-\mathrm{H})$ t.s. at the vascular bundle site of the leaf in control and stressed leaf respectively; (I) t.s. of leaf showing diaminobenzidine stained region around bulliform cells; (J-K) stomatal sites in 10x; (L-M) stomatal sites showing diaminobenzidine sites in $45 x$. 
Table 1. Content of proline, phenol and ascorbate in the leaves of four wheat varieties subjected to water stress.

\begin{tabular}{|c|c|c|c|c|}
\hline Varieties & Treatment & $\begin{array}{c}\text { Proline } \\
\left(\mathrm{mg} \mathrm{g}^{-1} \mathrm{dm}\right)\end{array}$ & $\begin{array}{c}\text { Phenol } \\
\left(\mathrm{mg} \mathrm{g}^{-1} \mathrm{dm}\right)\end{array}$ & $\begin{array}{l}\text { Ascorbate } \\
\left(\mathrm{mg} \mathrm{g}^{-1} \mathrm{dm}\right)\end{array}$ \\
\hline \multirow[t]{4}{*}{ KW } & $C$ & $2.0 \pm 0.02^{\mathrm{a}}$ & $29.9 \pm 0.05^{a}$ & $11.02 \pm 0.02^{\mathrm{a}}$ \\
\hline & $3 d$ & $2.9 \pm 0.02^{b}$ & $29.6 \pm 0.02^{b}$ & $12.19 \pm 0.02^{b}$ \\
\hline & $6 d$ & $8.1 \pm 0.03^{b}$ & $39.9 \pm 0.06^{b}$ & $13.44 \pm 0.04^{b}$ \\
\hline & $9 d$ & $10.8 \pm 0.02^{b}$ & $40.1 \pm 0.03^{b}$ & $14.78 \pm 0.09^{b}$ \\
\hline \multirow[t]{4}{*}{ LV } & $C$ & $1.7 \pm 0.05^{\mathrm{a}}$ & $38.4 \pm 0.10^{a}$ & $9.98 \pm 0.06^{a}$ \\
\hline & $3 d$ & $1.6 \pm 0.06^{\mathrm{a}}$ & $39.6 \pm 0.10^{b}$ & $9.90 \pm 0.01^{\mathrm{a}}$ \\
\hline & $6 d$ & $5.0 \pm 0.10^{b}$ & $44.0 \pm 0.01^{b}$ & $10.10 \pm 0.03^{b}$ \\
\hline & $9 d$ & $5.1 \pm 0.02^{b}$ & $34.0 \pm 0.01^{b}$ & $11.30 \pm 0.06^{b}$ \\
\hline \multirow[t]{4}{*}{ UP 2752} & C & $2.5 \pm 0.04^{\mathrm{a}}$ & $33.6 \pm 0.02^{\mathrm{a}}$ & $12.11 \pm 0.02^{\mathrm{a}}$ \\
\hline & $3 d$ & $2.3 \pm 0.05^{\mathrm{a}}$ & $31.0 \pm 0.05^{b}$ & $12.98 \pm 0.03^{b}$ \\
\hline & $6 d$ & $9.8 \pm 0.01^{b}$ & $46.8 \pm 0.02^{b}$ & $14.90 \pm 0.05^{b}$ \\
\hline & $9 d$ & $11.2 \pm 0.05^{b}$ & $30.1 \pm 0.04^{b}$ & $15.51 \pm 0.04^{b}$ \\
\hline \multirow[t]{4}{*}{ PBW 343} & $C$ & $1.7 \pm 0.06^{\mathrm{a}}$ & $36.8 \pm 0.05^{a}$ & $11.96 \pm 0.02^{\mathrm{a}}$ \\
\hline & $3 d$ & $2.3 \pm 0.05^{b}$ & $33.6 \pm 0.09^{b}$ & $13.15 \pm 0.01^{\mathrm{b}}$ \\
\hline & $6 d$ & $7.5 \pm 0.06^{b}$ & $40.8 \pm 0.05^{b}$ & $13.51 \pm 0.02^{b}$ \\
\hline & $9 d$ & $11.9 \pm 0.10^{\mathrm{b}}$ & $29.1 \pm 0.10^{b}$ & $15.81 \pm 0.03^{b}$ \\
\hline so & $\begin{array}{c}c \\
3 d \\
6 d \\
9 d\end{array}$ & $\begin{array}{l}1.5 \pm 0.02^{\mathrm{a}} \\
2.6 \pm 0.05^{\mathrm{b}} \\
4.9 \pm 0.01^{\mathrm{b}} \\
6.1 \pm 0.08^{\mathrm{b}}\end{array}$ & $\begin{array}{l}21.1 \pm 0.04^{a} \\
29.4 \pm 0.10^{b} \\
37.5 \pm 0.05^{b} \\
38.0 \pm 0.07^{b}\end{array}$ & $\begin{array}{l}11.07 \pm 0.04^{\mathrm{a}} \\
12.14 \pm 0.05^{\mathrm{b}} \\
13.89 \pm 0.01^{\mathrm{b}} \\
14.65 \pm 0.03^{\mathrm{b}}\end{array}$ \\
\hline
\end{tabular}

Means \pm standard error, $n=10$; Different superscripts in each column express significant difference with control at $\mathrm{p}=0.01$, in Student's t-test. C: control; d: days.

ascorbate and carotenoids in all the five wheat varieties in comparison to their respective control sets. According to the data there was an enhancement in the ascorbic acid accumulation in all the varieties under stress which continued after the $9^{\text {th }}$ day of stress (Table 1); on the other hand, it was observed that carotenoids showed an initial increase followed by a general decline after $3^{\text {rd }}$ day in the varieties under study. The highest decline was recorded in case of SO, LV and also to some extent in case of PBW 343 (Table 2).

The total antioxidant value showed an enhancement in its accumulation in the all varieties, but in the more tolerant varieties KW, UP 2752 and PBW 343, with the increase in the days of stress also this activity was maintained whereas in LV and SO the total antioxidant initially increased and then declined (Table 3).

There was a significant decrease in the total chlorophyll content in the varieties taken for study, the decline being much pronounced in case of the susceptible varieties. However, in case of the tolerant varieties, the decline was lesser. The ratio of $\mathrm{chl} \mathrm{a} / \mathrm{b}$ after an initial enhancement declined in all the varieties with the decrease being much more pronounced in case of SO and LV (Table 2).
Effect on leaf Membrane stability index: Membrane stability was expressed as \% relative injury and results revealed that water stress had significant effect on MSI (Table 3). Linear decrease occurred in MSI with the increase in the duration of stress. Higher MSI value was observed in the cultivar KW, UP 2752 and PBW 343 during the $6^{\text {th }}$ and $9^{\text {th }}$ day of stress. While after 6 and 9 days of water stress, maximum decrease was recorded in LV and SO.

\section{Accumulation of water-stress responsive} metabolites: Free proline content increased with the increase in the days and severity of stress in general with respect to the control (Table 1). The accumulation of free proline in KW, UP 2752 and PBW 343 on the onset of $9^{\text {th }}$ day of water stress was twice than that of free proline content found to be accumulated in LV and SO.

\section{DISCUSSION}

Results of the influence of water stress in water relations of wheat varieties showed that decrease in the RWC on the $9^{\text {th }}$ day of stress with respect to zero day (control) was lower in PBW 343, UP 2752 and KW (40.75, 
Table 2. Content of total chlorophyll, chlorophyll a/b ratio and carotenoids in the leaves of five wheat varieties subjected to water stress.

\begin{tabular}{|c|c|c|c|c|}
\hline Varieties & Treatment & $\begin{array}{l}\text { Total chlorophyll } \\
\left(\mathrm{mg} \mathrm{g}^{-1} \mathrm{fm}\right)\end{array}$ & Chlorophyll a/b ratio & $\begin{array}{l}\text { Carotenoids } \\
\left(\mathrm{mg} \mathrm{g}^{-1} \mathrm{fm}\right)\end{array}$ \\
\hline \multirow[t]{4}{*}{ KW } & $C$ & $0.90 \pm 0.04^{\mathrm{a}}$ & 1.57 & $0.044 \pm 0.002^{\mathrm{a}}$ \\
\hline & $3 d$ & $0.77 \pm 0.02^{b}$ & 1.66 & $0.051 \pm 0.001^{b}$ \\
\hline & $6 d$ & $0.49 \pm 0.02^{b}$ & 1.54 & $0.061 \pm 0.005^{b}$ \\
\hline & $9 d$ & $0.31 \pm 0.01^{\mathrm{b}}$ & 1.78 & $0.055 \pm 0.002^{b}$ \\
\hline \multirow[t]{4}{*}{ LV } & C & $1.22 \pm 0.05^{\mathrm{a}}$ & 0.70 & $0.048 \pm 0.003^{a}$ \\
\hline & $3 d$ & $0.41 \pm 0.04^{b}$ & 1.44 & $0.049 \pm 0.003^{a}$ \\
\hline & $6 d$ & $0.31 \pm 0.02^{\mathrm{b}}$ & 1.55 & $0.038 \pm 0.001^{b}$ \\
\hline & $9 d$ & $0.29 \pm 0.01^{b}$ & 0.89 & $0.029 \pm 0.002^{b}$ \\
\hline \multirow[t]{4}{*}{ UP 2752} & C & $2.30 \pm 0.07^{\mathrm{a}}$ & 1.47 & $0.050 \pm 0.001^{a}$ \\
\hline & $3 d$ & $0.75 \pm 0.06^{b}$ & 1.60 & $0.062 \pm 0.003^{b}$ \\
\hline & $6 d$ & $0.63 \pm 0.01^{b}$ & 1.59 & $0.052 \pm 0.002^{\mathrm{a}}$ \\
\hline & $9 d$ & $0.62 \pm 0.03^{b}$ & 1.66 & $0.038 \pm 0.001^{b}$ \\
\hline \multirow[t]{4}{*}{ PBW 343} & C & $1.73 \pm 0.05^{\mathrm{a}}$ & 1.19 & $0.047 \pm 0.003^{a}$ \\
\hline & $3 d$ & $0.86 \pm 0.03^{b}$ & 1.24 & $0.048 \pm 0.001^{a}$ \\
\hline & $6 d$ & $0.57 \pm 0.07^{b}$ & 1.97 & $0.042 \pm 0.001^{\mathrm{a}}$ \\
\hline & $9 d$ & $0.39 \pm 0.11^{b}$ & 1.93 & $0.037 \pm 0.001^{b}$ \\
\hline SO & $\begin{array}{l}c \\
3 d \\
6 d \\
9 d\end{array}$ & $\begin{array}{l}0.96 \pm 0.09^{\mathrm{a}} \\
0.62 \pm 0.05^{\mathrm{b}} \\
0.49 \pm 0.04^{\mathrm{b}} \\
0.31 \pm 0.01^{\mathrm{b}}\end{array}$ & $\begin{array}{l}1.34 \\
1.43 \\
1.38 \\
1.12 \\
\end{array}$ & $\begin{array}{l}0.041 \pm 0.002^{\mathrm{a}} \\
0.049 \pm 0.001^{\mathrm{a}} \\
0.042 \pm 0.005^{\mathrm{a}} \\
0.033 \pm 0.002^{\mathrm{a}}\end{array}$ \\
\hline
\end{tabular}

Means \pm standard error, $n=10$; different superscripts in each column express significant difference with control at $\mathrm{p}=0.01$, in Student's $\mathrm{t}$-test.

C: control; d: days.

Table 3. Effect of water stress on Cell membrane stability and total antioxidant activity.

\begin{tabular}{lccc}
\hline Varieties & Treatment & $\begin{array}{c}\text { Relative injury } \\
(\mathbf{\%})^{*}\end{array}$ & $\begin{array}{c}\text { Total antioxidant } \\
\text { activity** }^{*}\end{array}$ \\
\hline KW & C & 69.49 & 8.92 \\
& 3d & 56.25 & 15.25 \\
6d & 46.49 & 11.63 \\
LV & 9d & 38.24 & 9.64 \\
& C & 61.32 & 5.21 \\
& 3d & 52.52 & 10.40 \\
UP 2752 & 6d & 45.33 & 7.89 \\
& 9d & 29.32 & 6.88 \\
& C & 86.29 & 6.88 \\
PBW 343 & 3d & 79.91 & 19.22 \\
& 6d & 59.66 & 21.43 \\
& 9d & 40.41 & 39.53 \\
& C & 67.22 & 5.76 \\
S0 & 6d & 81.23 & 11.50 \\
& 9d & 67.58 & 15.30 \\
& C & 32.39 & 22.24 \\
& 3d & 69.44 & 7.12 \\
& 6d & 54.56 & 10.82 \\
& 9d & 49.64 & 9.88 \\
& & 30.33 & 4.02 \\
\hline
\end{tabular}

${ }^{*}$ CMS expressed as percent (\%) relative injury; * * free radical scavenging activity (total antioxidant activity) expressed as percent (\%) inhibition of DPPH absorbance.

C: control; d: days.
42.34 and $36.65 \%$ respectively) compared to SO and LV (52.67 and $52.93 \%$, respectively). Drought was found to decrease the RWC of plant leaves (Sánchez-Blanco et al., 2002). Previous studies have also confirmed that the ability to maintain higher RWC is one of the mechanisms of drought tolerance in plants (Farooqui et al., 2000; Chakraborty et al., 2002; Iqbal and Bano, 2009).

Water stress is inevitably associated with increased oxidative stress due to enhanced accumulation of ROS, particularly $\mathrm{O}_{2}^{-}$and $\mathrm{H}_{2} \mathrm{O}_{2}$ in chloroplasts, mitochondria, and peroxisomes. As a result, the induction of antioxidant enzyme activities is a general adaptation strategy which plants use to overcome oxidative stresses (Foyer and Noctor, 2003). The potential of APOX to metabolize $\mathrm{H}_{2} \mathrm{O}_{2}$ depends on the redox state of such compounds. APOX and GR are believed to act in conjunction for $\mathrm{H}_{2} \mathrm{O}_{2}$ scavenging during environmental stresses (Sairam and Saxena, 2000). It has been suggested that the coordinated activity of the different $\mathrm{H}_{2} \mathrm{O}_{2}$-scavenging enzymes play a part in the plant redox homeostasis (Foyer and Noctor, 2005).

Results of the present study reveal that in case of $\mathrm{KW}$, PBW 343 and UP 2752 activities of POX and GR showed an increase with the increase in the duration of water stress whereas activities of CAT, SOD and APOX declined 
after an initial increase. When compared to these varieties SO and LV showed either a decrease in activities at all days of water stress (CAT and SOD) or a lower increase in the activity of these antioxidative enzymes, following water stress and the severity of stress. These results indicate that, among the five varieties, antioxidant mechanisms in terms of antioxidative enzymes are enhanced in three of the varieties which can be considered potentially tolerant.

$\mathrm{H}_{2} \mathrm{O}_{2}$, resulting from the action of $\mathrm{SOD}$, is toxic to cells. Therefore, it is important that $\mathrm{H}_{2} \mathrm{O}_{2}$ be scavenged rapidly by the antioxidative defense system to water and oxygen (Guo et al., 2006). The over-expression of SOD, if accompanied by enhanced $\mathrm{H}_{2} \mathrm{O}_{2}$ scavenging mechanisms, like CAT and POD enzyme activities, has been considered as an important anti-drought mechanism to cope with oxidative stress during water deficit conditions. SOD is the first enzyme which is expressed in the antioxidant mechanism and it increased initially in the more tolerant varieties and was also involved in contribution to the initial accumulation of $\mathrm{H}_{2} \mathrm{O}_{2}$. However, following increase in the severity or days of water stress, SOD activity declined even in the tolerant varieties and POX metabolized the $\mathrm{H}_{2} \mathrm{O}_{2}$ produced, thus, a synergic activity of various enzymes is required for the attainment of tolerance (Chakraborty and Pradhan, 2011). It was observed in our study that though all antioxidative enzymes increased initially, POX and GR activities could be maintained at higher levels in the tolerant varieties and hence contributed to the defense response. This result is similar to the results as obtained by Abedi and Pakniyat (2010) who reported enhanced activities of SOD and decreased CAT activity. Enhancement of GR activity in tolerant varieties indicated that tolerant plants exhibit a more active ascorbate-glutathione cycle than the less tolerant cultivars. This cycle has been implicated in mitigating the effects of ROS (Molina et al., 2002; Mandhania et al., 2006). In the present study, POX showed a much pronounced or greater role in mechanism for imparting tolerance compared to CAT following increase in the degree of water stress. This was in accordance with the results obtained by Chakraborty et al. (2002) in their study on tea cultivars. However, in the study of Iqbal and Bano (2009) a greater increase in POD and CAT activities in wheat accessions was reported in both tolerant and susceptible plants following water stress.

Varieties which were less tolerant accumulated higher amount of $\mathrm{H}_{2} \mathrm{O}_{2}$ and the increase in the lipid peroxidation were remarkably higher in case susceptible varieties than the tolerant ones. Various previous workers reported similar results (Chai et al., 2005; Zlatev et al., 2006) as we obtained. The decline in CAT activity was in correlation with the increase in the accumulation of $\mathrm{H}_{2} \mathrm{O}_{2}$ following water stress as well as increased lipid peroxidation in all varieties. The enhanced $\mathrm{H}_{2} \mathrm{O}_{2}$ levels under water deficit would be alleviated through the combined action of CAT and APX. Foyer and Noctor (2012) have suggested that serious problems persist in our ability to actively extract, assay and accurately quantify $\mathrm{H}_{2} \mathrm{O}_{2}$ in tissues or extracts which are fraught with ambiguities. Such problems, according to him may be addressed by the development of biochemically suitable staining techniques. In our studies the detection of cellular levels of $\mathrm{H}_{2} \mathrm{O}_{2}$ was done by $D A B$ staining method and our results shows a clear difference in the degree of staining achieved in the control and the stressed plant.

Lipid peroxidation in the cell membranes is said to be one of the most challenging and detrimental effect of water stress in the membranes of all the cells exposed to varied degree of stress as quoted by Thankamani et al. (2003) and the degree of lipid peroxidation measured in terms of MDA content is one of the determinants which indicates the severity of stress experienced by any plant. Other workers like Tatar and Gevrek (2008) have also reported increase in MDA content with increase in the degree of stress in wheat. In addition, Türkan et al. (2005) found that MDA content was lower in the leaves of drought-tolerant Phaseolus acutifolius Gray. than that in drought-sensitive $P$. vulgaris L. Sairam and Srivastava (2001) reported that the drought-tolerant genotypes of wheat showed lower lipid peroxidation level and higher MSI value than the susceptible ones which is in conformity with the present findings.

Small antioxidants such as ascorbate and carotenoids also increased in tolerant varieties. According to Nair et al. (2008) there was a decrease in ascorbate content in susceptible varieties of cowpea when the degree of water stress increased. Increased ascorbate accumulation was reported by Jaleel (2009) in his study in Withania somnifera following water stress. Enhancement in the accumulation of ascorbic acid and increase in GR hints to the occurrence of ascorbate-glutathione cycle as a predominant mechanism of ROS detoxification. The overall antioxidant activity of all varieties showed an initial increase in all varieties, which was still high even after 9 days of stress in the tolerant varieties but, in the other two varieties, the total antioxidant activity declined after 6 days.

Decrease in chlorophyll content and an increase in proline accumulation was observed in the present study. Several workers have reported higher proline levels in 
plants subjected to water stress conditions. Hsu et al. (2003) studied the effect of PEG-induced water stress at $-1.5 \mathrm{MPa}$ and observed accumulation of proline and its precursor's glutamic acid, ornithine and arginine in rice leaves. The high correlation between proline accumulation and drought-tolerance increase has also been described; however, such accumulation can be only a stress effect (Parida and Das, 2005). Several workers like Vendruscolo et al. (2007), Tatar and Gevrek (2008) have considered proline as an osmotolerant whose accumulation in the cell system suggests its active involvement the scavenging of free radicals thus by reducing damage caused by various kinds of oxidative stress. In our study it was determines that in KW, UP 2752 and PBW 343, phenol contents increased with increase in the duration of the stress, though in the other two varieties the accumulation of total phenol decline or remained unchanged during the $9^{\text {th }}$ day. Leinhos and Bergman (1995) had studied the plant defense system against various types of stress with respect to the involvement of polyphenols as a response to stress, also other workers such as Chakraborty et al. (2002) had studied and reported that the accumulation of phenols was greater in case of tolerant cultivars of tea.

It was indicated by the results of our study that water stress was responsible for the induction of oxidative stress and thus related damage as shown by RWC decrease, increase in the MDA content (i.e., lipid peroxidation), $\mathrm{H}_{2} \mathrm{O}_{2}$ accumulation, degradation of chlorophyll molecule, enhanced antioxidative responses as evident in the differential or varied levels of antioxidative enzyme activities, accumulation of different antioxidants like carotenoids, ascorbate, phenols and osmolytes such as soluble sugars. Out of the five varieties taken for the study, KW, UP 2752 and PBW 343 showed a much more pronounced antioxidative mechanisms after the induction of water stress and hence, they seem to be protected from the detrimental effects or damage caused by oxidative stress as a result of water stress even at the longer duration and increased severity of stress. CMS as well as difference in the percent relative injury among the varieties served as important criteria to study the effects of water stress and also to determine the susceptible and tolerant variety. Considering all the above data our study showed that KW, Up 2752 and PBW 343 were more tolerant varieties, whereas LV and SO were less tolerant or, in other words, more susceptible to water stress.

Acknowledgements: Authors are grateful to University Grants Commission, New Delhi, India, for financial assistance.

\section{REFERENCES}

Abedi T, Pakniyat H (2010) Antioxidant enzyme changes in response to drought stress in ten cultivars of Oilseed Rape (Brassica napus L.). Czech. J. Gen. Plant. Breed. 46:27-34.

Asada K, Takahashi M (1987) Production and scavenging of active oxygen in photosynthesis. In: Kyle DJ, Osmond CB, Arntzen CJ, editors. Photoinhibition. Amsterdam: Elsevier Science Publishers. pp.227-287.

Bates HS, Waldren RP, Treare ID (1973) Rapid estimation of free proline for water stress determination. Plant Soil 39:205-208.

Beers R, Sizer I (1952) A spectrophotometric method for measuring the breakdown of hydrogen peroxide by catalase. J. Biol. Chem. 195:133-140.

Blois MS (1958) Antioxidant determination by the use of standard free radicals. Nature 181:1199-2000.

Bray HG, Thorpe WV (1954)Analysis of phenolic compounds of interest in metabolism. Meth. Biochem. Anal. 1:27-52.

Chai TT, Fadzillah NM, Kusnan M, Mahmood M (2005) Water stress-induced oxidative damage and antioxidant responses in micro propagated banana plantlets. Biol. Plant. 49:153-156.

Chakraborty U, Chakraborty BN, Kapoor M (1993) Changes in the levels of peroxidase and phenyl alanine ammonia lyase in Brassica napus cultivars showing variable resistance to Leptosphaeria maculans. Fol. Microbiol. 38:491-496.

Chakraborty U, Dutta S, Chakraborty BN (2002) Response of tea plants to water stress. Biol. Plant. 45:557-562.

Chakraborty U, Pradhan B (2011) Drought stress-induced oxidative stress and antioxidative responses in four wheat (Triticum aestivum L.) varieties. Arch. Agron. Soil Sci. 58:617-630.

Chen WP, Li PH, Chen THH (2000) Glycinebetaine increases chilling tolerance and reduces chilling-induced lipid peroxidation in Zea mays $\mathrm{L}$. Plant Cell Environ. 23:609-618.

Dhindsa RS, Dhindsa PL, Thrope TA (1981) Leaf senescence: correlated with increased levels of superoxide dismutase and catalase. J. Exp. Biol. 32:93-101.

Farooq S, Azam F (2002) Co-existence of salt and drought tolerance in Triticaceae. Hereditas 135:205-210.

Farooqui AHA, Kumar R, Fatima S, Sharma S (2000) Response of different genotype of lemon grass (Cymbopogaon flexuosus and $C$. pendulus) to water stress. J. Plant Biol. 27:277-282.

Foyer C, Noctor G (2003) Redox sensing and signalling associated with reactive oxygen in chloroplasts, peroxisomes and mitochondria. Plant Physiol. 119:355-364.

Foyer CH, Noctor G (2012) Managing the cellular redox hub in photosynthetic organisms. Plant Cell Environ. 35:199-201.

Foyer CH, Noctor G (2005) Redox homeostasis and antioxidant signalling: A metabolic interface between stress perception and physiological responses. Plant Cell 17:1866-1875.

Foyer CH, Noctor $\mathrm{G}$ (2000) Oxygen processing in photosynthesis: regulation and signaling. New Phytol. 146:359-388.

Gechev TS, Gadjev I, Van Breusegem F, Inze D, Dukiandjiev S, Toneva V, et al (2002) Hydrogen peroxide protects tobacco from oxidative stress by in ducing a set of antioxidant enzymes. Cell Mol. Life Sci. 59:708-714. 
Gratao PL, Polle A, Lea PJ, Azevedo RA (2005) Making the life of heavy metal-stressed plants a little easier. Funct. Plant Biol. 32:481-494.

Guo Z, Ou W, Lu S, Zhong Q (2006) Differential responses of antioxidative system to chilling and drought in four rice cultivars differing in sensitivity. Plant Physiol. Biochem. 44:828-836.

Harborne JB (1973) Phytochemical methods. London: Chapman and Hall.

Heath RL, Packer L (1968) Photoperoxidation in isolated chloroplasts I:Kinetics and stoichiometry of fatty acid peroxidation. Arch. Biochem. Biophys. 125:189-198.

Hsu SY, Hsu ST, Kao CH (2003) The effect of polyethylene glycol on proline accumulation in rice leaves. Biol. Plant. 1:73-78.

Imlay JA (2003) Pathways of oxidative damage. Annu. Rev. Microbiol. 57:395-418.

Iqbal S, Bano A (2009) Water stress induced changes in antioxidant enzymes, membrane stability and seed protein profile of different wheat accessions. African J. Biotech. 8:6576-6587.

Jaleel CA (2009) Non-Enzymatic Antioxidant Changes in Withania somnifera with varying drought stress levels. Am. Eur. J. Sci. Res. 4:64-67.

Jena S, Choudhuri MA (1981) Glycolate metabolism of three submerged aquatic angiosperms during aging. Aquat. Bot. 12:345-354.

Lawlor DW, Cornic G (2002) Photosynthetic carbon assimilation and associated metabolism in relation to water deficits in higher plants. Plant Cell Environ. 25:275-294.

Lee DH, Lee CB (2000) Chilling stress-induced changes of antioxidant enzymes in the leaves of cucumber in gel enzyme activity assays. Plant Sci. 159:75-85.

Leinhos V, Bergmann H (1995) Changes in the yield, lignin content and protein patterns of barley (Hordeum vulgare cv. Alexis) induced by drought stress. Angew. Bot. 69:206-210.

Lichtenthaler K (1987) Chlorophylls and carotenoids pigments of photosynthetic biomembranes. Meth. Enzymol. 148:350-382.

Lowry OH, Rosebrough NJ, Fair AL, Randall RJ (1951) Protein measurement with folin phenol reagent. J. Biol. Chem. 193:265-275.

Mahadevan A, Sridhar R (1982) Methods of physiological plant pathology. 2a. ed. India: Sivakami.

Mandhania S, Madan S, Sawhney V (2006) Antioxidant defense mechanism under salt stress in wheat seedlings. Plant Biol. 50:227-231.

Mittler R (2002) Oxidative stress, antioxidants and stress tolerance. Trends Plant Sci. 7:405-410.

Molina A, Bueno P, Marin MC, Rodriguez-Rosales MP, Belver A, Venema $\mathrm{K}$, et al (2002) Involvement of endogenous salicylic acid content, lipoxygenase and antioxidant enzyme activities in the response of tomato cell suspension culture to NaCl. New Phytol. 156:409-415.

Mukherjee SP, Choudhuri MA (1983) Implications of water stress induced changes in the levels of endogenous ascorbic acid and H2O2 in Vigna seedlings. Plant Physiol. 58:166-170.

Nair AS, Abraham TK, Jaya DS (2008) Studies on the changes in lipid peroxidation and antioxidants in drought stress induced cowpea (Vigna unguiculata L.) varieties. J. Environ. Biol. 29:689-691.

Nayyar H, Gupta D (2006) Differential sensitivity of C3 and C4 plants to water deficit stress: Association with oxidative stress and antioxidants. Environ. Exp. Bot. 58:106-113.
Parida AK, Das AB (2005) Salt tolerance and salinity effects on plants - a review. Ecotox. Environ. Saf. 60:324-349.

Pastori GM, Foyer CH (2002) Common components, networks and pathways of cross-tolerance to stress. The central role of 'redox' and abscisic-acidmediated controls. Plant Physiol. 129:460-468.

Premchandra GS, Saneoka H, Ogata S (1990) Cell membrane stability, an indicator of drought tolerance as affected by applied nitrogen in soybean. J. Agri. Sci. 115:63-66.

Sairam RK (1994) Effect of moisture stress on physiological activities of two contrasting wheat genotypes. Indian. J. Exp. Biol. 32:594-597.

Sairam RK, Saxena DC (2000) Oxidative stress and antioxidants in wheat genotypes: possible mechanism of water stress tolerance. J. Agro. Crop. Sci. 184:55-61.

Sairam RK, Srivastava GC (2001) Water stress tolerance of wheat (Triticum aestivum $\mathrm{L}$.): Variations in hydrogen peroxide accumulation and antioxidant activity in tolerant and susceptible genotypes. J. Agron. Crop. Sci. 186:63-70.

Sanchez-Blanco MJ, Rodrgiuez P, Morales MA, Ortuo MF, Torrecillas A (2002) Comparative growth and water relations of Citrus albidus and Citrus monspeliensis plants during water deficit conditions and recovery. Plant Sci. 162:107-113.

Sang Y K, Jung-Hyun L, Myoung RP, Young JK, Tae II P, Yong WS et al (2005) Enhanced antioxidant enzymes are associated with reduced hydrogen peroxide in barley roots under saline stress. J. Biochem. Mol. Biol. 38:218-224.

Snyrychova I, Ferhan A, Eva H (2009) Detecting hydrogen peroxide in leaves in vivo - a comparison of methods. Physiol. Plant. 135:1-18.

Suzuki N, Koussevitzky S, Mittler R, Miller G (2012) ROS and redox signalling in the response of plants to abiotic stress. Plant Cell Environ. $35: 259-270$.

Tas S, Tas B (2007) Some physiological responses of drought stress in wheat genotypes with different ploidity in Turkiye. World J. Agric. Sci. 3:178-183.

Tatar 0, Gevrek MN (2008) Influence of water stress on proline accumulation, lipid peroxidation and water content of wheat. Asian J. Plant Sci. 7:409-412

Thankamani CK, Chempakam B, Ashokan PK (2003) Water stress induced changes in enzymatic activities and lipid peroxidation in black pepper (Piper nigrum).J. Med. Aromat. Plant Sci. 25:646.

Thordal-Christensen H, Zhang Z, Wei Y, Collinge DB (1997) Subcellular localization of $\mathrm{H} 2 \mathrm{O} 2$ in plants : $\mathrm{H} 2 \mathrm{O} 2$ accumulation in papillae \& hypersensitive response during the barley - powdery mildew interactions. Plant J. 11:1187-1194.

Tripathy JN, Zhang J, Robin S, Nguyen TH, Nguyen HT (2002) QTL for cellmembrane stability mapped in rice (Oryza sativa L.) under drought stress. Theor. Appl. Genet. 100:1197-1202.

Turkan I, Bor M, Ozdemir F, Koca H (2005) Differential response of lipid peroxidation and antioxidants in the leaves of droughttolerant $P$. Acutifolius Gray and drought-sensitive P. vulgaris L. subjected to polyethylene glycol mediated water stress. Plant Sci. 168:223-231.

Upadhyaya H, Khan MH, Panda SK (2007) Hydrogen peroxide induces oxidative stress in detached leaves of Oryza sativa L. Genet. Plant Physiol. 33. 1-2:83-95. 
Vendruscolo ACG, Schuster I, Pileggi M, Scapim CA, Molinari HBC, Marur CJ, et al (2007) Stress-induced synthesis of proline confers tolerance to water deficit in transgenic wheat. J. Plant Physiol. 164:1367-1376.

Vranova E, Inze D, Van Breusegem F (2002) Signal transduction during oxidative stress. J. Exp. Bot. 53:1227-1236.
Yordanov I, Velikova V, Tsonev T (2003) Plant responses to drought and stress tolerance. Bulg. J. Plant Physiol. Special Issue:187-206.

Zhu JK (2002) Salt and drought stress signal transduction in plants. Annu. Rev. Plant Physiol. 53:243-273.

Zlatev ZS, Lidon FC, Ramalho JC, Yordanov IT (2006) Comparison of resistance to drought of three bean cultivars. Plant Biol. 50:389-394. 